\title{
O PATENTEAMENTO DE MOLÉCULAS BIOLÓGICAS NATLRAIS NOS EUA E UNIÃO EUROPÉIA
}

\author{
PATENTEABILITY OF NATURAL BIOLOGIC MOLECULES IN THE USA AND ELROPEAN UNION
}

Vladimir Garcia Magalhães

\begin{abstract}
Resumo:
O Direito de Propriedade Industrial e seu ramo Direito de Patentes tutelam juridicamente as invenções humanas novas e com utilidade industrial. As invenções se distinguem das descobertas pelo fato de não serem pré-existentes e resultarem da atividade criativa humana. Nos EUA, o USPTO United States Patent and Trademark Office, órgão estatal para concessão de patrentes, permite o patenteamento de moléculas biológicas naturais extraídas \& isoladas dos organismos, inclusive os genes e scu DNA, com a justificativa de que elas não existem nesta forma pura em seu estado natural mas sim associadas à outras moléculas e que a Constituição c a Lei de Patentes americana utilizam o termo "descobertas" para autorizar a proteção por patentes. Na União Européia o patenteamento de moléculas naturais é previsto na Diretiva 98/44/EC, art. 3.2. A Convenção de Munique sobre Patentes Européias em seu art. 52.2.a, contudo. veda expressamente a concessão de patentes para descobertas. Ocorrc que não existe atividade inventiva nas moléculas simplesmente isoladas da natureza se constituindo em descobertas e não invenções. Assim, esta Diretiva conflita com a Convenção de Munique. que lhe é hierarquicamente superior.
\end{abstract}

Palavras-chave: Propriedade Intelectual. Direito de Patentes. Moléculas Biológicas Naturais. Biodiversidade. Direito Internacional. Direito Comparado. Direito Ambiental. Biotecnologia. DNA.

\begin{abstract}
:
International Property Law and its branch Patent Law disposes legally new human invents with industrial application. Inventions distinguish from discoveries, due to the fact of not being pre-existent and result of human creative activity. In the USA, the USPTO - United States Patent and Trademark Office, official agency for grant of patents, allow the patent of natural biological molecules extracted and isolated from organisms, including genes and their DNA, according the assertion that these products don't exist in pure format in their natural state, only when associated to other molecules; American Constitution and Patent Act refer to "discoveries" to allow their protection by patents. In the European Union, patent of natural molecules is estahlished in Directive 98/44/EC, article 3.2. Munich Convention on European Patents, in article 52.2.a, however, prohibits the grant of patents for discoveries. The fact is there is not inventive activity in molecules simply isolated from nature, and is classified as discovery, not as an invention. So. this Directive conflicts with the Munich Convention. which is hierarchically higher.
\end{abstract}

Advogado (USP) e biólogo (USP), mestre e doutor em Dircito Intemacional pela laculdade de Direito da Universidade de São Paulo, professor do curso de mestrado em Direito Ambiental da I'niversidade Católica de Santos, UNISANTOS 
Keywords: International Property. Patent Law. Natural Biological Molecules. Biodiversity. International Law. (omparative Law. Environmental Law. Biotechnology. DNA.

\section{Introdução}

O desenvolvimento da biotecnologia e suas técnicas, como a engenharia genética, notadamente a partir da década de 80 e nos países mais desenvolvidos, ampliou de modo radical as possibilidades de exploração comercial, particularmente pela indústria farmacêutica, dos recursos biológicos, como o material genético dos seres vivos, encontrados no meio ambiente natural.

Em decorrência deste fato, as empresas de biotecnologia nos países desenvolvidos passaram a procurar a tutela juridica dos seus interesses e a obter direito de monopólio sobre as moléculas naturais descobertas na Natureza e sua utilização comercial, através do direito de patente.

Este trabalho tem por objetivo analisar criticamente a legislação dos EUA, e sua interpretação pelo United States Patent and Trademark Office (USPTO), e também a legislação comunitária da União Européia, que fundamentam, juridicamente, este procedimento, à luz da doutrina clássica sobre o direito de patentes c Convenção de Munique sobre Patentes Européias de 1973.

Inicialmente, fazemos um breve resumo sobre a propriedade intelectual, seu histórico e modalidades, a seguir sistematizamos os conceitos doutrinários. jurisprudenciais e legais de invenção para distinguir estas das descobertas e a seguir analisamos os argumentos do USPTO, para permitir o patenteamento de moléculas biológicas naturais, a Lei de Patentes americana e a Diretiva 98/44/EC da União Furopéia, que permite expressamente este patenteamento, em relação ao disposto pela Convenção de Munique sobre Patentes Européias.

2. A propriedade intelectual

2.1 Aspectos Gerais

$\Lambda$ propriedade intelectual é o produto da atividade intelectual humana nos campos industrial. científico e literário e tutelada pelos direitos de propriedade intelectual. As justificativas dadas, pela doutrina em geral, para a edição de leis para a proteção da propriedade intelectual são basicamente: proteger legalmente, o direito moral e econômico dos criadores sobre as suas criações, assim como o direito do público de acesso a estas criações: promover como política governamental, a criatividade, a 
disseminação e a aplicação dos seus resultados e estimular um comércio que contribua para o desenvolvimento econômico e social.

Fm termos gerais, o direito de propriedade intelectual objetiva proteger o criador, e outros produtores de bens e serviços intelectuais, garantindo a eles certos direitos limitados no tempo para controlar, com exclusividade, a utilização dos produtos do seu trabalho intelectual e criatividade.

Esses direitos não se aplicam aos objetos materiais nos quais as criações se materializam, mas sim na criação em si mesma. A propriedade intelectual divide-se em propriedade industrial e em direitos autorais (copyright).

As produções literária, artística e científica correspondem aos direitos autorais. As áreas de perfomances artísticas tais como discos e programas de rádio são usualmente chamadas de direitos conexos aos direitos autorais.

O direito de propriedade industrial abrange as invenções, os desenhos industriais, as marcas e os nomes comerciais. As invenções são protegidas pela patente. que é um documento publicado pelo Estado, e que descreve uma invenção e também cria um direito de exclusividade para o solicitante pelo qual a invenção só pode ser utilizada mediante a autorização do detentor da sua patente.

A sua origem remonta aos privilégios comerciais da Idade Média concedidos pelos soberanos, de modo pessoal e discricionário. O mais antigo privilégio comercial na Idade Média de que se tem registro é o concedido em 1236 pelas autoridades municipais de Bordeux a Bonafusus de Sancta Columbia para tecer e tingir lã para as roupas, utilizando os métodos flamenco, francês e inglês. O privilégio tinha duração de quinze anos e caráter de exclusividade.'

Em 1331, na Inglaterra. o Rei Eduardo III concedeu a John Kempe, tecelão flamenco, um privilégio comercial para convencê-lo a introduzir no pais a indústria da tecelagem. também com tempo de duração determinado e em caráter de exclusividade. $^{2}$ Em 1440, foi concedido o privilégio de exclusividade a John di Shiedame por um método de fabricação do sal e, em 1449, o mesmo ocorreu a John di Utynam, pela fabricação do vidro. Em 1558, o italiano Tomaso Chanata, juntamente com o inglês Geo Cobham apresentaram uma petição à Rainha para o uso exclusivo de uma máquina de polir. Estes são alguns exemplos das primciras concessões de exclusividade e são a raiz do que hoje conhecemos como privilégio de patente. ${ }^{3}$

FRANCESCHELLI. Remo. Tratado di diritto industrial'. Parte generale, v.I. Milano: Giuffre Ed., 1973. p. $285-286$.

Hulme, E. W., 1896 apud FRANCESCHELLI, Remo. op. cit.. p. 286.

FRANCESCHELLI. Remo. up. cil., p. 286-287. 
A proteção concedida pela patente é limitada no tempo. Em geral, no máximo por vinte anos. Em alguns países, as invenções são protegidas também pelo registro, sob o nome de modelo de utilidade. Os requisitos para concessão de registro de modelo de utilidade são menos restritivos que os da patente de invenção, em particular no que tange à etapa inventiva. Em comparação com as patentes, o seu tempo de proteção é mais curto. Por outro lado, os direitos relativos aos modelos de utilidade são semelhantes aos da patente. Os requisitos para concessão de patente são a novidade, a existência de atividade inventiva e a utilidade industrial.

A indiana Vandana Shiva (200I) faz algumas restrições aos direitos de propriedade intelectual. Segundo ela, a sociedade humana sempre produziu conhecimentos trocados livremente entre as pessoas até o século XIX, com o surgimento do direito de propriedade intelectual tal qual o conhecemos hoje. A partir desse momento, essa troca deixou de ser livre porque o conhecimento passou a ser objeto de direitos privados. Ela entende assim que os direitos de propriedade intelectual significam a privatização do conhecimento.

Outra restrição da autora é que eles somente são reconhecidos quando têm utilidade industrial, ou seja, geram lucros. E não quando satisfazem necessidades sociais. $O$ requisito da utilidade industrial exclui todos os setores, como as comunidades tradicionais, que criam fora da organização industrial capitalista, mas inovando e produzindo do mesmo modo que ela. Em suas palavras:

O lucro e a acumulação de capital são os únicos fins da criatividade; o bem social não é mais reconhecido. Sob o controle das corporações, ocorre a "desindustrializaşão" das produções em pequena escala nos setores informais da sociedade.

Questionando o argumento de que o sistema de direitos de propriedade intelectual é necessário para compensar a inventividade e estimulá-la. Shiva aponta estudos de Reich (1985) que concluem que não existem evidências concretas de que as patentes estimulem de fato novas invenções. Elas seriam mais utilizadas para bloquear a entrada de outras empresas no mercado. Um instrumento para a sua monopolização. Cita o exemplo de que após a extensão da proteção às variedades de plantas e o estabelecimento nos tribunais americanos do entendimento de se conceder patentes de organismos. diminuiu consideravelmente o número de empresas independentes de produção de sementes nas últimas décadas. O mercado de sementes estaria se oligopolizando nas mãos de empresas gigantes da área petroquímica e farmacêutica. ${ }^{4}$

REICH. Leonard, 1985 apud SHIVA. Vandana. Rinpiralaria. Petrópolis: Vozes, 2001. p. 35. 
Ela aponta ainda interessantes dados de estudos, que indicaram que as patentes não eram essenciais para o desenvolvimento de novas invenções nas áreas de produção de equipamentos elétricos, material de escritório, automóveis, instrumentos, metal primário, borracha, e materiais têxteis. Nas indústrias de petróleo, maquinaria e produtos metálicos fabricados, estimou-se que as patentes eram essenciais para o desenvolvimento de aproximadamente de $10 \%$ a $20 \%$ das suas invenções. Somente para as indústrias químicas e farmacêuticas, é que foram julgadas essenciais para $80 \%$ das invenções. $^{\text {s }}$

Assim, ela conclui que para a maioria das áreas de atividade industrial, as patentes não são necessárias para estimular novas invenções. Sua utilidade seria mais como um poderoso instrumento de controle de mercado, pelo direito de exclusividade (monopólio) sobre o objeto da patente. Considera ainda que as patentes enfraquecem a criatividade social dos cientistas por inibir a comunicação entre eles, imprescindível para o processo de criação científica, pelo fato deles recearem perder a prioridade no patenteamento do que desenvolveram em seus laboratórios ou de que outra pessoa patenteie seu trabalho. Assim. paradoxalmente, as patentes exploram a criatividade científica que lhes fornece o substrato de conhecimento básico, sem o qual as invenções patenteáveis não seriam desenvolvidas e, ao mesmo tempo, inibem essa criatividade. acabando assim com a sua própria fonte. ${ }^{6}$

Além disso, as formas tradicionais de classificação da produção intelectual e sua proteção jurídica, não contemplam formas coletivas de produção intelectual, como o folclore e os conhecimentos tradicionais.

\subsection{Patentes: Invenção e Descoberta}

Todo o conceito do direito de patentes foi construído sobre a premissa de que ele tutelaria as invenções humanas em decorrência do julgamento de que seria justo uma pessoa ter direitos sobre suas idéias, quando elaboradas em nível suficiente para se traduzirem em uma utilidade industrial. Se a indústria vai lucrar com uma idéia, porque não o seu autor?

Ocorre que ao longo de dezenas de anos a partir de seu surgimento e com o desenvolvimento da biologia molecular e da biotecnologia moderna resultante dela, cujo uso comercial resulta em valores financeiros muito expressivos, começou a se desconstruir nos países desenvolvidos a essência histórica do direito de patentes. Esses países começarem a deixar de distinguir invenção de descoberta. Isso tem sido feito na

SHIVA, Vandana, op. cit., p. 36.

Id. ibid.. p. 36-37. 
prática, através de interpretações tendenciosas da legislação existente, deturpando os seus objutivos originais, como ocorre nos EUA e através da criação de uma legislação que permite expressamente o patenteamento de descobertas como ocorre na União Européia (UE).

A novidade da invenção, e que é requisito para concessão da patente, não é a novidade nos registros de patentes, ou seja, ser o primeiro pedido de patente daquela invenção. É a novidade de existência conhecida. Não é necessário que uma invenção tenha sido patenteada para que esta mesma invenção criada por outra pessoa, que desconhecia a sua existência anterior, deixe de ser nova. Por isso as patentes obtidas a partir de conhecimentus tradicionais foram anuladas no mundo inteiro: elas não foram consideradas novas.

Este processo realizado pelos governos dos países desenvolvidos de lentar eliminar a diferença conceitual entre invenção e descoberta está gerando um novo direito de propriedade intelectual e de patentes. Muito distinto do que surgiu no século XIX e existe até hoje nos demais países do planeta. É um direito construído exclusivamente para garantir os fabulosos lucros reais e potenciais das empresas multinacionais com origem e sede nesses países.

Contudo, é também um direito que ainda não conseguiu construir uma doutrina sólida o suficiente para legitimar esse processo de desvirtuamento do direito de propriedade intelectual criado originariamente. Essa gênese e desconstrução de conceitos com mais de um século de existência do direito de patentes, deve ser lenta e sutil para ser bem-sucedida. É. exatamente isto que está ocorrendo atualmente.

Por isso e para se apropriarem dos recursos da biodiversidade dos países em desenvolvimento e dos conhecimentos das comunidades tradicionais do mundo inteiro, através do direito de exclusividade sobre eles, é que esse novo direito de propriedade intelectual e sua doutrina, que os países desenvolvidos tentam sutilmente globalizar, tem começado a destruir a separação conceitual e legal entre invenção e descoberta, pois esta última sempre foi excluida do direito de propriedade intelectual pela doutrina, desde os scus primórdios.

As legislações sobre propriedade industrial quase nunca definiram o que seja invenção, porque elas surgiram em época de grandes transformações e avanços na tecnologia. Com isso, os legisladores temiam inserir essa definição e deixar a lei descompassada com a realidade das novas invenções, preferindo deixar ao judiciário e à doutrina a tarefa de elaborar as definições de acordo com a realidade de cada época. 
Nas palavras de Ramella (1909), justificando a exclusão de definições de invenção nas leis: ${ }^{7}$

anzi l'applicazione del principio omnis definito in jure periculosa trova giustificazione soprattuto nel campo della tecnica e delle industrie, esposte a incessante progresso, ed al pericolo quindi che una legale definizione dell'oggi non corrisponda il alle esigenze di un avvenire non lontano, una volta rinserrato il concetto d'invenzione negli stretti termini dell'adottata definizione. ${ }^{8}$

Esse vácuo conceitual que sempre foi deixado nas leis européias e americana foi muito oportuno e essencial para viabilizar esse movimento das empresas dos países desenvolvidos e seus governos, de transformar o direito de propriedade intelectual existente em um novo direito habilitado a ser instrumento eficaz para a apropriação do rico patrimônio biológico e de conhecimentos tradicionais dos países em desenvolvimento. Ainda que tal apropriação não seja permanente, pois a patente tem existência temporária, o prêmio envolvido para essas empresas são décadas de exclusividade de uso comercial e, portanto. bilhões de dólares de lucros.

Assim, por razões de justiça e de integridade científica do direito de propriedade industrial para que ele e a doutrina jurídica não se desmoralizem por casuísmos gerados pela ganância de empresas transnacionais, é necessário que analisemos o que são a invenção e a descoberta, assim como as diferenças essenciais entre esses dois conceitos, pois somente invenções podem ser objeto do privilégio de patente, as descobertas, não. ${ }^{y}$

\subsubsection{A Invenção}

As invenções são definidas em raras leis de alguns paises, também pela doutrina e pela jurisprudência, ambas fontes formais do direito, como a própria lei c o costume.

RAMELLA, Agostino. Tratrato della proprietà industriale. v.1- le invenzione industriali. Roma: Soc. Editrice Laziale, 1909. p. 66.

8 Traduzimos como "diante da aplicação do princípio omnis definito in jure periculosa se encontra justificativa, sobretudo no campo da técnica e da indústrı expostas ao incessante progresso e ao pcrigo, portanto. de que uma definição legal de hojc não corresponda às exigências de um futuro não distante, uma vez encerrada a invenção nos estreitos termos da definição adotada"

9 DOMINGUES. Douglas (jabricl. Direito Industrial e Patentes. Rio de laneiro: Forense, 1980. p. 30) 


\subsubsection{Definições Doutrinárias}

Burnier (1981) faz uma compilação de doutrina européia sobre o conceito de invenção que reproduzimos abaixo, para extrairmos o elemento comum a todas: ${ }^{10}$

Kohler (1900) define que "l'invention est une création intellectuelle de l'esprit humain exprimée techniquement, qui assujettit un noveau domaine de la nature et vise avec succès à satisfaire des exigences de l'être humain par l'utilisation de forces naturelles." (grifamos)

Allard (1911) define invenção como sendo "une création de l' esprit se produisant dans le domaine de i'industrie et se manifestant par l'obtention d'un résultat industriel" ${ }^{12}$ (grifamos)

Seligsonhn (1932): "En règle générale, l'invention est une création qui. réalisée par l'utilisation des forces de la nature, présent un progrès essentiel par rapport à l'état actuel de la technique et satisfait un besoin humain" ${ }^{13}$ (grifamos)

Offermann (1949): "Une invention est la solution d'un problème technique obtenue grâce à une idée créatice et réalisant un progrès technique" ${ }^{14}$ (grifamos)

Blum (1965): "Toutefois, toute invention doit représenter une règle régissant un acte technique. L'invention est donc par essence abstraite: c'est une idée, une création intellectuelle" is (grifamos)

Rotondi (1965): "L'invention serait la solution concrète d'un problème technique dès lors qu elle constitue une création de l'esprit humain dépassant les connaissances et applications usuelles de la technique contemporaine" 16 (grifamos)

Troller (1968): "L'invention, au sens du droit suisse des brevets, es une règle d'utilisation des forces de la nature, crée par une ou plusiers personnes, et qui, à la

16 BURNIER, Dominique. La notion de l'invention en droit europén des brevets. Genève: Librairie Droz, 1981. p. 22-25.

"Traduzimos como "a invenção é uma criação intelectual do espirito humano expressa tecnicamente, que submete uma nova área da natureza, objetivando a atender com sucesso às necessidades do ser humano na utilização das forças naturais" (grifamos).

12. Traduzimos como "uma criação do espirito que ocorre na área da indústria e que se manisfesta na obtenção de um resultado industrial". (grifamos).

13 Traduzimos como "como regra geral, a invenção é uma criação que, concretizada na utilização das furças da natureza. apresenta um progresso fundamental em relação ao estado atual da técnica. atendendo a uma necessidade humana". (grifamos)

12 Traduzimos como "a invenção é a sulução de um problema tícnico, obtida atravès de uma idèia criativa c realizando um progresso técnico" (grifamos).

15 Traduzimos como "Qualquer invenção deve representar a regulação de um ato lécnico. A invenção por sua própria natureza é abstrata: é uma idéia, uma criaçāo intelectual." (grifamos).

16 Traduzimos como "A invenção será a solução concreta de um problema técnico desde que constitua uma criação do espirito humano. ultrapassando o conhecimento $\mathrm{e}$ as aplicaçōes usuais da técnica contemporânea." (grifamos). 
date du dépot de la demande de brevet, pouvait réaliser un progrès technique reconnaissable et n etait pas, à cette date, évident pour l'homme du métier" "17 (grifamos)

Bernhardt (1973): “L'invention est une création intellectuelle, qui indique comment obtenir, au moyen d'une connaissance nouvelle découlant de l'utilisation de la nature, un résultat inconnu auparavant. qui satisfait des besoins humains d'une manière originale et constitutive de progrès" ${ }^{18}$ (grifamos)

Sena (1976): "L'invention peut etre définie comme une crèation intellectuelle consistant dans solution d'un problème technique" 19 (grifamos)

Schick (1978): “Une invention est une création utile revêtant l'aspect d'une découvert, c'est-à-dire, une acquisition utile qui procède à la fois d'une création et d'une découverte, l'une et l'autre se situant dans un rapport de réciprocité" ${ }^{20}$ (grifamos)

Silveira (1987), define a invenção industrial como a "criação no campo da indústria" 21 Transcrevemos abaixo:

Estabelecido o princípio de que a proteção da lei visa resguardar a criação original do autor e que. no campo da invenção industrial, trata-se daquelas criações que produzem um efeito no mundo físico (...). ${ }^{2}$ (grifamos).

Giuletti, referindo-se à invenção. afirma:

Infatti il significato attuale secondo un accezione prevalente viene assimilato a quello di creazione e serve a indicare "I'operare umano in quanto produce qualcosa di nuovo, qualcosa che prima non c'era" 23

1. Traduzimos como "A invenção - na compreensão do direito suiço de propriedade intelectual - ¿ u uma regra de utilização das forças da natureza, criada por uma ou várias pessoas. e que na data do registro da propriedade representa um progresso técnico reconhecido e, até então. desconhecido naquela área." (grifamos).

18 Traduzimos como "A invenção é uma criação intelectual que indica como obter, através de um novo conhecimento de utilização da natureza, um resultado desconhecido até então, que atende às necessidades humanas de maneira original e representativa de progresso." (grifamos).

19 Traduzimos como "A invenção pode ser definida como uma criação intelectual que visa à solução de um problema técnico." (grifamos).

20 Traduzimos como "Uma invenção é uma criação útil revestindo o aspecto de descoberta, isto é, uma aquisição útil que, simultaneamente, representa uma criação e uma descoberta, ambas mantendo uma relação de reciprocidade." (grifamos).

21 SILVEIRA. Newton. Curso de propriedade industrial. 2. ed. São Paulo: Ed. Revista dos Tribunais. 1987. p. 13.

22 Id. ibid., p. 16.

23 Traduzimos cumo "De fato. o significado atual segundo o entendimento predominante vem associado àquele de criação e serve para indicar a obra humana quando produz algo novo, algo que antes não existia" (grifamos). In: GIULETTI apud VIARO, Mario. La Iurela del principio scientifico nel diritto d'imvenzione. Milano: Giuffrè, 1970. p. 27. 
Ascarelli ${ }^{24}$ diz que "un apporto creativo deve necessariamente caratterizzare l'invenzione" ${ }^{25}$ (grifamos).

Di Sabato e Lo Iudice (1982) definem e dividem a invenção em duas categorias: a invenção principal e a derivada. A principal é a invenção que aplica pela primeira vez um conhecimento científico à esfera industrial. Ela é desenvolvida a partir de uma descoberta, sem que ambas se confundam. A descoberta é um componente de base da invenção principal sem a qual ela não poderia existir. Invenção derivada, no conceito desses autores é aquela desenvolvida a partir de uma outra invenção, aperfeiçoando-a ou inovando-a com sua aplicação em novos setores industriais. ${ }^{26}$

Nas palavras desses autores: ${ }^{27}$

L'essenza dell'invenzione è stata individuata nella nuova soluzione di un problema tecnico. la quale con un'idea originale apporti un sostanziale miglioramento nel campo dei prodotti industriali ovvero dei processi o metodi di produzione.

El'invenzione si concretizza in una nuova combinazione delle force naturale (...)

Emerge daquanto sopra che attività inventiva è per ciò stesso attività creativa (...).(grifamos)

Ghiron (1937) afirma que não há privilégio de exclusividade sem invenção e analisa os seus elementos. O elemento objetivo é o aumento da utilidade anterior existente, sendo que esta é definida como sendo a satisfação de uma necessidade humana. O elemento subjetivo é a atividade criativa. ${ }^{28}$

Esse Autor, ao analisar o elemento subjetivo da invenção, ou seja, o seu caráter criativo, cita que a jurisprudência italiana da época tinha a tese de que "è suscettibile di privativa l'invenzione solo allorchè porta al campo delle utilità preesistcnte un contributo creativo individuale"29 (Trib Milano, 14 diccmbre 1931). Não importa o grau de criatividade, mas sim que ela exista em um grau mínimo suficiente para que se reconheça a sua existência. ${ }^{30}$ Se não houver criatividade, não poderá haver. portanto, direito de exclusividade.

24 ASCARELLI, apud VIARO, Mario. op. cit., p. 43.

25 Traduzimos como "uma contribuição criativa deve caracterizar uma invenção"

26 DI SABATO, Franco: LO IL DICE, Bruno. Innovazioni lechnologiche e diritto di empresa. 2. ed. Vapoli: Morano Ed.. 1982. p. 97.

27 Id. ibid., p. 38.

28 GHIRON, Mario. Corso di dirillu industriale. 2. ed. rev. e ampl. Roma: Socictá liditrice del "IForo Italiano", 1937. v. 2. p. 209.

29 Traduzimos como "é suscetivel de privilćgio somente as invenções que trazem ao campo da utilidade préexistente uma contribuição criativa individual". (grifamos).

30 GHIRON, Mario. op. cil.. p. 212. 
Toda a doutrina enumerada, ao detínirmos invenção, tem em comum o fato de apontar a existência de criatividade na atividade inventiva, o que resulta em invenção. Ghiron, em análise brilhante, indica que ela é um dos elementos constitutivos, o elemento subjetivo da invenção. Assim, podemos concluir que, do ponto de vista doutrinário. em matéria de patente, concordamos com ele. Ele afirma ainda onde não há invenção não existe privilégio de exclusividade; então, podemos dizer que onde não há atividade criativa. não pode haver direito de exclusividade, pois, não há atividade inventiva e a patente é. nos termos das leis nacionais e acordos internacionais, aplicável somente às invenções.

\subsubsection{Definições Jurisprudenciais}

Viaro $(1970)^{31}$ cita jurisprudência italiana definindo invenção, que transcrevemos abaixo:

l'invenzione è la nuova soluzione di un problema tecnico atto a concrete realizzazione nel campo industriale e requisito essenziali per la sua tutela è la novità da considerarsi sotto un duplice aspetto, e cioè estrinseca ed intrinsica; la novità estrinsica sussiste allorchè il ritrovato industriale rappresunta un quid novi nel senso che era precedentemente ignoto a chiunque, mentre la novità intrinsica consiste nell'apporto creativo originale dell'inventore $(\ldots)^{32}$ (Cass. 4 marzo 1968 n 682 in Giust. Civ., 1968, I, 791; Rep. Foro it., 1969, col. 2039, n.13.) (grifamos)

Burnier (1981) cita jurisprudência do Tribunal Federal da Suíça, em suas primeiras decisões sobre a matéria, nesse mesmo sentido: ${ }^{33}$

Une invention suppose toujours une pensée créatice
produisant un résult technique nouveau, un effect teclunique
différent de de qui était connu jusque-Jà. (RO 16, 592
$(596)=$ JT 1890, 529 (531). ${ }^{34}$ (grifamos). réalisation d'un progrès essentiel de la technique, d'un effect technique utile, grâce à une combinaison nouvelle

II VIARO, Mario. op. cit., p. 37.

32 Traduzimos como "A invenção é a nova solução de um problema técnico apta à concreta efetivação no campo industrial e requisito essencial para a sua tutela, $\dot{i}$ a novidade considerada sob um duplo aspecto. $O$ extrinseco e o intrinseco; a novidade extrínseca existe quando a descoberta industrial representa um quid novi no sentido de que era anteriormente desconhecida por todos, enquanto a novidade intrínseca consiste na contribuição criativa original do inventor”. (grifamos)

BURNIER, Dominique. op. cit., p. 26.

is Traduzimos como "Uma invençào pressupōe sempre um pensamento criativo produzindo um rusultado técnico novo, um efeito técnico diferente do que era conhecido até então". 
et originale des forces de la nature. (RO 26II 229 $(232)) .^{35}$ (grifamos).

il y a une invention lorsqu'un effect technique utilc et par conséquent, un progrès technique sont obtenus par la réalisation d'une idée originale, créatrice" (RO 63 II 271JT 1938 I $40(41)^{36}$ (grifamos).

Nas decisões posteriores, o Tribunal Federal da Suíça desistiu de definir invenção e passou a enumerar seus elementos constitutivos como na ação A. G. Contra Hymmen K. G: ${ }^{37}$

Il y a une invention, au sens de l'article ${ }^{\text {er }}$ al. LBI, lorsque la règle technique en laquelle elle consist réalise un progrès technique clairement reconnaissable et, en même temps, implique un niveau inventif, c'est-à-dire qu'elle ne se trouve pas dans le rayon des solutions que l'état de la technique au moment du dépôt de la demande de brevet mettait à la portée de l'homme de métier doté d'une bonne formation moyenne: mais qu'elle résulte d'une prestation créatrice, qui va au-delà d'une telle évolution. (RO 92 II 48 (5I s.) 1976)..$^{38}$ (grifamos)

No processo Canguilhem contra Office Fédéral de la Propriété Intellectuelle:

Selon la doctrine et la jurisprudence, on se trouve en présence d'une invention lorsque, grâce à une idće créatrice, une combinaison nouvelle et originale des forces de la nature, dans l'acception la plus large de cette expression, aboutit à un cffet technique utile, constituant un progrès notable. L'invention n'est ni la force naturelle comme telle, ni le produit de son utilisation. C'est la règle abstraite dont la répétition conduit à un résultat technique déterminé. susceptible d’application

35 Traduzimos como "realização de um progresso essencial da técnica, de um efeito técnico útil. graças à uma combinação nova e original das forças da natureza." (grifamos)

36 Traduzimos como "há uma invenção quando um efeito técnico útil e. conseqüentemente, um progresso técnico, são obtidos pela realização de uma idéia original, criativa". (grifamos)

37 BURNIER, Dominique. op. cit., p. 27.

38 Traduzimos como "Há uma invenção no scntido do art. $1^{\circ}, \mathrm{I}, \mathrm{BI}$, quando a regra técnica na qual ela consiste, realiza um progresso técnico claramente reconhecivel, e, ao mesmo tempo, implica num nivel inventivo, ou seja, que ela não se encontra na área das soluções que o estado da técnica no momento do depósito da patente põe ao alcance do homem de oficio dotado de uma boa formação média; mas que ela resulte de uma prestação criadora que vai além de uma tal cvolução" 
industrielle. ${ }^{39}$ (RO 98 Ib 396 (399)- confirmation do RO 95 I 579 (581 e arrêts citées). (grifamos)

Conforme o entendimento dessa decisão, as forças da natureza utilizadas na invenção não são invenção. Logo, os componentes da invenção que não tenham sido criados, não poderiam ser objeto do direito de exclusividade temporária que a concessão da patente gera. As moléculas biológicas naturais e as informações nelas contidas são parte da natureza, logo, à luz desse entendimento, não poderiam ser patenteadas nem objeto de direito de exclusividade em uma invenção nelas baseada.

\subsubsection{Definições Legais}

As leis que definem invenção são muito raras. O Reino Unido define invenção na Lei de Patentes (Patent Act) de 16 de dezembro de 1949, em seu artigo 101.(1), que diz:

101.(I)- "invention" means any manner of new. manufacture the subject of letters patent and grant of privilege within section six of the Statute of Monopolies and any new method or process of testing applicable to the improvement or control of manufacture, and includes an alleged invention: ${ }^{40}$

No Japão. a Lei n. 121 de 13 de abril de 1959, em seu artigo 2.1 define que "Invention' in this Law means the highly advanced creation of technical ideas by which a law of nature is utilized" ${ }^{\text {"4l }}$ (grifamos). Portanto. como podemos observar. também a criação está presente, como elemento essencial e constituinte da invenção.

\subsubsection{No Vernáculo}

Em português, a palavra invenção se origina da palavra latina inventione, e o seu significado é:

invenção. (do lat. Inventione). S.f. I- Ato ou efeito de inventar, de criar, de engendrar. 2- Coisa nova criada ou concebida no campo da ciência, tecnologia ou das artes.

39 Traduzimos como "Segundo a doutrina e a jurisprudência, encontramo-nos em presença de uma invenção quando, graças a uma idéia criativa, uma combinação nova e original das forças da natureza, na acepção mais abrangente dessa expressão, atinge-se um efeito técnico útil, constituindo um progresso notável. A invençāo nāo é nem a força natural como tal, nem o produto de sua utilizaçāo". (grifamos).

* Traduzimos como "invenção signilica qualquer modo de fabricação de um produto, objeto de patente e concessão de privilégio, contidos na seção seis do Estatuto dos Monopólios e qualquer novo método ou processo aplicável au melhoramento ou controle de fabricação. inclusive da alegaưa invenção".

"Traduzimos como "Invenção nessa Lei significa a criação altamente avançada de ideiias ticnicas, pelas quais uma lei da natureza é utilizada". (grifamos). 
(...) 5. Novo meio ou expediente para alcançar um fim; criação, descoberta.(...). ${ }^{42}$ (grifamos).

Devemos perceber, que o item 5 dos significados desse vocábulo, coloca o significado descoberta como seu sinônimo. Ocorre que toda invenção pode também ser considerada uma descoberta, porque tem o componente da novidade, ou seja, de não existir antes, justamente por ter sido criada; mas nem toda descoberta pode ser também considerada uma invenção, como veremos a seguir.

\subsubsection{A Descoberta}

O Tratado de Genebra sobre o Registro Internacional de Descobertas Científicas, de 1978, define em seu art. $1^{\circ}$ (i), a descoberta científica como sendo:

o reconhecimento de fenômenos, propriedades ou leis do universo material, até então desconhecidos e passiveis de serem verificados.

O que é patenteado nos EUA e na UE, são justamente as propriedades das moléculas contidas em sua estruturas químicas, que são descritas nas solicitações de patentes. Por exemplo, a seqüência de DNA que constitui um gene. se estiver dentro de um sistema biológico ou em um sistema artificial que reproduza o sistema biológico, tem a propriedade de ser traduzida em uma proteina. Talvez justamente pelo fato de tornar muito evidente que as patentes de moléculas biológicas são patentes sobre descobertas científicas e não-invenção, esse tratado não tenha entrado em vigor até pelo menos novembro de $1999 .^{43}$

\section{Ramella (1909) conceitua: ${ }^{44}$}

...è pure scoperta la conoscenza di nuove qualità di certi corpi, es. L'azione febbrifuga del chinino, o la constatazione che l'unione di due sostanze note, forman un corpo nuovo, ecc. ${ }^{45}$

La scoperta cosi caratterizzata non rientra nelle previsione della legge sulle privative, chè non si concedono attestati

42 HOLANDA, Aurélio Buarque de. Novo Dicionário da Lingua Porluguera. 2. ed. Rio de Janeiro: Ed. Nova Fronteira, 1986. p. 964.

43 WIPO- World Intellectual Property Organization, National Seminar un Innovation Promotion. Genebra, WIPO/INN/BRI/99/1, 1999. p. 17.

44 RAMELLA, Agostino. up. cil., p. 68-69.

45 Traduzimos como "é apenas descoberta o conhecimento de novas qualidades de certos corpos. por exemplo, a ação antitérmica do quinino, ou a constatação de que a união de duas substâncias conhecidas formam um corpo novo clc." 
per scoperta d'un corpo nuovo o di nuove qualità di esso o di nuove leggere di natura. ${ }^{46}$

Il fatto però è che la scoperta apre facile il passo alla'invenzione, chè chi abbia del primo avvertita la qualità particolare d'un corpo potrà più facilmente, e anteriormente a ogni altro, utilizzare la scoperta per realizzare un'invenzione, es. Creando nuoviprodotti colla combinazione di determinate sostanze chimiche ed al seguito delle loro conosciute proprietà. ${ }^{47}$ (grifamos)

Em português, descoberta significa:

1. Aquilo que se descobriu ou encontrou por acaso ou mediante busca, pesquisa, observação, dedução ou invenção: A descoberla do ouro no Brasil deu-se no séc. XVII; a descoberta da penicilina; a descoherta de um novo planeta. (...)3. Achado, invenção, inovação. ${ }^{48}$ (grifamos)

Burnier (1981) define descoberta como sendo "l'action d'apercevoir ce qui était inconnu, par exemple une chose existante et jamais constatée, la propriété ignorée d'une matière ou les effects non relevés d'un pheenomène" e acrescenta: "Le découvert ne crée rien de nouveau, elle se situe au niveau de la connaissance" 49

\subsubsection{A Diferença e Relação entre Invenção e Descoberta}

Para analisarmos se algo pode ser objeto do privilégio de patente temos. em primeiro lugar, que analisar se se trata de uma invenção ou de uma descoberta. Para isso são necessárias a identificação dos elementos essenciais desses conceitos tão semelhantes e a identificação de suas diferenças.

Ramella (1909) diferenciou bem a invenção da descoberta: ${ }^{.0}$

La scoperla suppon sempre una cosa già esistente, l'invenzione invece un a cosa nuova che non esisteva anteriormentc. Colla prima si metton in luce, si riconoscon

46 Traduzimos como "A descoberta assim caracterizada não entra na previsão da lei de propriedade, que não concede atestado pela descoberta de um corpo novo, ou de novas qualidades, ou de novos entendimentos da natureza."

47 Traduzimos como: "O fatu, porém, é que a descoberta abre caminho facilmente para a invenção, porque quem tiver primeiramente percebido as qualidades particulares de um corpo poderá mais facilmente. e antes de qualquer uutro. utilizar a descoberta para chegar a uma invenção. por ex. criando novos produtos com a combinação de detcrminadas substâncias quimicas e cm seguida de suas propricdades."

4 HOLANDA, Aurélio Buarque de. op. cit. p. 551.

J. Traduzimos como: "a ação de compreender u que cra desconhecido, por exemplo, uma coisa existente e jamais constatada, a propriedade ignorada de uma matéria, ou os efeitos não-reviclados de um fenômeno" "A descoberta não cria nada de novo, ela se situa ao nivel do conhecimento". BURNIER, Dominique. op. cit., p. 160.

50 RAMELLA. Agostino. op. cit.. p. 67. 
oggetti, fenomeni e proprietà di corpi la cui esistenza non era ancora constatata, che sfuggita all'osservazione altrui; colla seconda si creano nuovi effetti tecnici, per scopo di soddisfacimento di bisogni economici, combinando ed utilizzando forze della natura. ${ }^{51}$ (grifamos).

Allart $(1911)^{52}$ diz que a Lei de 5 julho, de 1844 da França, utiliza as expressões "décourvertes et inventions" e conclui que isso ocorre por causa das duas palavras serem sinônimas no latim. E faz a distinção entre "inventer, c'est produire une chose qui n existait pas encore" e "découvrir, c'est metre en lumiére une chose qui existait, mais qui n'était pas connue" 54

Burnier (1981) exemplifica a diferença: ${ }^{55}$

Ainsi, on parlera de découvert dans le cas d'un élément chimique précédemment inconnu (parce que cet élément préexistant et etait seulement inconnu de l'homme jusqu'à sa découvert). En revanche. on parlera d'invention dans le cas d'un nouveau composé chimique crée par une manière particulière de combiner l'élément qui vient d'être découvert et d'autres éléments ou composés chimiques (parce que le nouveau composé n'était pas préexistant) ${ }^{56}$ (grifamos).

Bonelli (1957) ${ }^{57}$ diferencia descoberta e invenção de modo muito acurado. Transcrevemos suas palavras:

la scoperta consiste nella rivelazione di un fenomeno già esistente, di un corpo o delle sue proprietà, di una leggere naturale o di un principio, col risultato di arricchire il patrimonio della cultura, ma senza che da essa derivi direttamente, como invece accade nelle invenzioni, alcuna modificazione nel preesistente stato oggetivo delle cose'. 'Ia scoperta è antitesi de creazione, la quale è invece, il

${ }_{1}$ Traduzimos como "A descoberta supõe sempre algo jả existente, a invenção, ao contrário, supõe uma coisa nova ainda nào existente. Com a primeira se indicam. se reconhecem objetos, fenomenos e propriedades de corpos cuja existência não fora ainda detectada, ou que fugira à observação de alguém: com a segunda, se criam novos efeitos técnicos com o propósito de atender a necessidades cconòmicas, combinando e utilizando as forças da natureza."

s2 ALLART. Henri. Traité Théorique el Pratique des Brevels d'lnvention. 3. ed. Paris: Arthur Rousseau ed, 1911. p.3.

53 Traduzimos como "inventar, é produzir algo que ainda não existe"

54 Traduzimos como "descobrir, evidenciar uma coisa que existe, mas que não era conhecida"

ss BURNIER. Dominique. op. cit., p. 162.

s6 Traduzimos como "Assim. se falará em descoberta no caso de um elemento químico anteriormente desconhecido (porque este elemento preexistia e era somente desconhecido do homem até a sua descoberta). Por outro lado, se falará em invenção no caso de um novo composto quimico criado por uma maneira particular de combinar o elemento que foi descoberto com outros elementos ou compostos químicos (porque o novo composto não era preexistente).

s7 Apud VIARO, Mario. op. cit., p. 30 . 
nucleo essenziale della nozione di invenzione' 'Esistono però dei collegamenti tra invenzione e scoperte, perche le primo formiscono i mezzi e aumentano le possibilità di scoperte, mentre, per converso. molto spesso le invenzioni hanno la loro premessa in una scoperta scientifica. ${ }^{58}$ (grifamos)

A EPC-Convenção Européia sobre Patentes (Convenção de Munique) de 1973, em seu art. 52, também distingue descoberta e invenção sem, contudo, definir nenhuma das duas, mas excluindo expressamente a descoberta do sentido de invenção, conforme podemos observar no seu texto transcrito abaixo:

Artigo 52.

Invenções patenteáveis

I - As patentes européias são concedidas para as invenções novas que implicam uma actividade inventiva e são susceptiveis de aplicação industrial;

2. Não são consideradas como invenções no sentido do parágrafo I particularmente;

a) As descobertas assim como as teorias cientificas $e$ os mérodos matemáticos (...): (grifamos).

Assim, podemos observar que em todas as definições doutrinárias, jurisprudenciais e dicionarizadas a essência da invenção é o ato criativo. Ela passou a ser tutelado pelo Direito, porque é fruto da imaginação e da inteligência do inventor, para que houvesse uma justa contrapartida, pois a invenção resulta em colocar à disposição da indústria e da sociedade novos processos e produtos que não existiam antes. É justamente essa capacidade inventiva do ser humano que fez civilização e as sociedades humanas mudarem tão radicalmente seu modo de vida desde os seus primórdios.

Já a descoberta não tem componente criativo em si. Os fenômenos, as leis e os demais elementos que compõem a natureza existem independentemente do ser humano, que somente aos descobri-los passa a ter conhecimento desses fenômenos

38 Traduzimos como "A descoberta consiste na revelação de um fenômeno já existente, de um corpo ou sua propriedade, de uma lei natural ou do principio, cujo resultado é o enriquecimento do patrimônio da cultura, mas sem que dela derive diretamente, ao contrário ocorre na invenção alguma modificação no preexistente estado concreto de alguma coisa: a descoberta é a antitese da criação, a qual é o núcleo essencial da noção de invenção; existem, porém, ligações entré invenção e descoberta, porque a primeira fornece os meios e aumenta as possibilidades da descoherta. e por outro lado, com freqüência. as invenções tèm sua premissa em uma descoberta cientifica" 
preexistentes a ele e à sua vontade ou criatividade. Logo, a descoberta é apenas a revelação para o ser humano desses fenômenos naturais. Nada é criado nesse processo.

Existe uma estreita e dialética relação entre ambas. As descobertas permitem à ciência evoluir e conseqüentemente também às invenções que dela resultam e que vão constituir a tecnologia. A tecnologia, por sua vez, cria instrumentos que nos permitem conhecer melhor os fenômenos naturais, fazendo novas descobertas.

Assim, o conhecimento dos átomos permitiu que se construísse o acelerador de particulas atômicas o qual, por sua vez, permitiu maior conhecimento sobre os átomos, suas características e propriedades. As descobertas sempre foram excluídas do privilégio de patente por não haver ato criativo humano na descoberta em si. $O$ ato criativo existe na definição do processo pelo qual vai se fazer a descoberta.

Essa relação estreita existe também pelo fato de ambas as palavras terem a mesma raiz latina inventione. Além disso, quando se inventa algo que não existia antes, ou seja, quando se cria, como não se podia conhecer o que não existia antes por ainda não ter sido criado, esse algo é criado e simultaneamente descoberto por quem o criou. $\mathrm{O}$ que não existe ainda, obviamente é também desconhecido. Por isso se usa comumente o termo descoberta para uma invenção.

De modo diferente quando se descobre algo já existente, mas desconhecido, não pode se dizer que isso foi inventado, porque nada foi criado. Ele já existia e somente era desconhecido. Assim, toda invenção é simultaneamente uma descoberta, mas nem toda descoberta é também uma invenção.

Não havendo criação não há invenção nem pode haver privilégio de patente, caso contrário estaríamos diante da situação absurda de que a natureza e todos os seus fenômenos e elementos, seriam patenteáveis e, conseqüentemente, também todas as descobertas cientificas.

Por isso mesmo o patenteamento de moléculas biológicas naturais contraria frontalmente o direito de propriedade industrial existente até aqui, como veremos a seguir.

Com o progresso das modernas áreas da biotecnologia nas últimas décadas, que resultaram em novas técnicas, como a engenharia genética, os recursos genéticos e o DNA que os constituem, assim como os outros metabólitos primários e secundários existentes nos organismos pertencentes à biodiversidade do planeta se tornaram extremamente estratégicos do ponto de vista econômico e político. gerando um 
grande interesse por eles da parte de quem não os têm e deles necessita como matériaprima para a biotecnologia.

Conseqüentemente, uma legislação de patentes ambientalmente e socialmente correta, deve levar isso em conta tanto nos diplomas internacionais, relativos a esta matéria como o TRIPS e a CBD, quanto nas legislações nacionais dos paises que detêm tal biodiversidade.

Além do DNA, que constitui os genes, outras moléculas biológicas também se tornaram muito importantes econômica e comercialmente. Como conseqüência disso, em grande parte dos países desenvolvidos, como os EUA e países da União Européia, estão sendo concedidas patentes de moléculas biológicas naturais. Inclusive de genes humanos e de seu DNA.

\subsubsection{EUA}

Em 12 de abril de 1988, os EUA concederam patente sob o n. 4.736.866, para um rato transgênico. Ao que consta foi a primeira patente concedida para um animal transgênico no mundo, ${ }^{59}$ mas não foi a última.

Aponta-se que entre 1981 e 1995 se concederam 1.175 patentes para seqüências de DNA humano em todo o mundo. Nos EUA, através de uma série de decisões que partem do Caso Amgen e culminam com o Caso Deuel, firmou-se uma corrente jurisprudencial favorável ao patenteamento irrestrito das seqüências de DNA através da simplificação ou eliminação de requisitos objetivos da patenteabilidade, ${ }^{60}$ como a inventividade.

O USPTO- United States Patent Trademark Office tem concedido patentes de seqüências de DNA de genes humanos ou de outros organismos, bastando que eles tenham sua função biológica indicada, sem que elas necessitem de ser provadas, e discute pormenorizadamente todos os questionamentos levantados contra esse patenteamento em um artigo publicado. Não podemos esgotar nesse trabalho uma análise desse guia de patentes e dos argumentos elencados nesse artigo, mas apontamos os principais que são utilizados para justificar o patenteamento de genes e outras moléculas biológicas naturais.

A esse respeito, transcrevemos abaixo. ${ }^{61}$

iq SOARES, José Carlos T. Biotecnologia- A mais avançada tecnologia da vida. Revista da ABPI. Rio de Janeiro: n. 10, p. 38-40, 1994.

BERGEL. Salvador D. Patente de Genes: Implicâncias Éticas e Juridicas. Bioètica, v. 5, n. 2, p. 245.

6! ESTADOS UNIDOS DA AMÉRICA. Department of Commerce. USPTO- United States Patent and Trademark Office. Utility Examination Guidelines. Washington: Federal Register, v. 66, n. 4, p. $1.092-$ 1.093, Friday, January 5, 2001. 
Several comments state that while inventions are patentable, discoveries are not patentable. According to the comments, genes are discoveries rather than inventions. These comments urge the USPTO not to issue patents for genes on the ground that genes are not inventions. Response: the suggestion is not adopted. An inventor can patent a discovery when the patent application satisfies the statutory requirements. The U.S.Constitution uses the word discoveries where it authorizes Congress to promote progress made by inventors. ${ }^{62}$

Obviamente, o sentido em que foi utilizado o termo descoberta no texto constitucional americano foi o de sinônimo de invenção, o que era comum nas legislações do século XIX, como aponta Ramella (1909), ${ }^{63}$ justamente por serem sinônimos, quando a invenção é criada sendo assim, ao mesmo tempo, descoberta como já discutido neste trabalho. O USPTO aproveita-se disso para que o direito de propriedade industrial nos EUA tenha um aparente fundamento jurídico para patentear moléculas biológicas descobertas.

O Lei de Patentes dos EUA, emendada em 13 de dezembro de 2003, se refere à patenteabilidade de invenções e garantia de patentes em sua seção 100 nos seguintes termos "(...)The term invention means invention or discovery" 64

O USPTO, interpreta a lei americana, citando a seção $10 \mathrm{l}$, da Lei de Patentes dos EUA, nos seguintes termos: ${ }^{05}$

When Congress enacted the patent statutes, it specifically authorized issuing a patent to a person who "invents or discovers" a new and useful composition of matter, among other things. The pertinent statute is 35 U.S.C. 101, which reads: "Whoever invents or discovers any new and useful process, machine, manufacture, or composition of matter, or any new and useful improvement thereof, may obtain a patent therefore, subject to the conditions and requirements of this title" 66

22 Traduzimos como: "Vários comentários declaram que enquanto invenções são patenteáveis, descobertas não o são. Segundo eles, us genes são mais descobertas du que invenções. Esses comentários solicitam com urgência ao USPTO para não conceder patentes para genes pelo motivo deles não serem invenções. Resposta: A sugestão não é aceita. $O$ inventor pode patentear uma descoberta quando o requerimento de patente satisfaz as exígências estabelecidas em Lei. A Constituição dos EUA usa a palavra "descobertas" quando autoriza o Congresso a promover o progresso feito pelos inventores.

63 RAMELLA, Agostino. op. cit., p. 67.

os Traduzimos como: "o termo invenção significa invenção ou descoberta"

is ESTADOS UNIDOS DA AMERICA. Department of Commerce. USPTO- United States Patent and Trademark Office. op. cit., p. 1.092-1.093.

66 Traduzimos como: "Quando o Congresso promulgou a legislação de patentes, autorizou especificamente a concessão de patente à pessoa que "inventa ou descobre" uma nova e útil composição de substâncias, entre outras coisas. A Lei pertinente é a 35 USC. 101. que diz "Todo aquele que inventa ou descobre qualquer processo. máquina, produto industrial ou composição de substãncia que seja novo c útil, ou um novo e útil 
Thus, an inventor's discovery of a gene can be the basis for a patent on the genetic composition isolated from its natural state and processed through purifying steps that separate the gene from other molecules naturally associated with it. ${ }^{6 ?}$

Ocorre que Domingues (1989) explica que o uso da palavra descoberta não é uniforme nas diversas legislações nacionais e que a Lei de Patentes americana, usa como sinônimo para invenção. ${ }^{68}$

Diz esse autor:

Nos EUA, o emprego dos termos de descoberta e invenção como sinônimos, tem origem histórica na Constituição americana: o art. $1^{\circ}$, Sec. 8 , conferindo ao Congresso poderes para promover o progresso da ciência e das artes, assegurando aos inventores direito exclusivo sobre suas descoberlas por prazo limitado, deu motivo a que a primeira lei de patentes americana, Patent Act de 1790. estabelecesse: o interessado ao formular o pedido de patente deveria afirmar que havia inventado ou descoberto alguma coisa útil, usando as duas palavras como sinônimos. Hoje, a Patent Laws. Capitulo 10, Sição 100, esclarece: o termo invenção significa invenção ou descoberta, salvo se o texto expressamente dispuser diferente.

Em relação à interpretação da lei pelos tribunais americanos ele acrescenta: "Em 1862, caso Morton v. Infarmary, firmou-sc o entendimento que leis da natureza, podem ser descobertas mas não podem ser patenteáveis como invenção" e ainda:

Em 1889, no pedido de patente ex parte Latimer, The Comissioner of Patents dos EUA firmou o princípio seguinte: o verdadeiro produto da natureza "tecido celular da árvore pinus australis, liberado de resina, partes da polpa e agulhas... não pertence à classe dos objetos patenteáveis". ${ }^{69}$

Assim, quando o USPTO faz referência à lei americana de patentes, faz também dela uma interpretação equivocada. distorcida e casuística. Obviamente, o texto legal americano citado está usando os dois termos como sinônimos, mas considerando o

aperfeiçoamento deles, pode obter a patente, sujeita às condições e exigências deste direito"

67 Traduzimos como: "Assim, a descoberta de um gene, por um inventor, pode ser a base para a patente de um material genético isolado do seu estado natural e purificado, o que separa o gene de outras moléculas naturalmente assuciadas à ele"

68 DOMINGUES, Douglas Gabriel. Privilégios de invenção, engenharia genética e biotecnologia. 1. ed. Rio de Janeiro: Forense, 1980. p.91.

69 Id. Ibid., p.92. 
sentido de invenção, de criação de algo, senão toda a descoberta científica nos EUA, fora da área biológica, poderia também ser patenteada. Aliás, qualquer elcmento da natureza isolado dela poderia ser patenteado, inclusive os átomos que compõem as moléculas, o que obviamente não-ocorre.

No entendimento do USPTO, para se patentear um gene ou outra molécula biológica natural, basta que eles sejam isolados dos tecidos naturais e tenham uma utilidade industrial, que nem precisa ser provada, apontada na solicitação de patente. Ela precisa ser apenas plausível para o avaliador do pedido ${ }^{70}$ como observamos no trecho transcrito abaixo:

That is, where the application discloses a specific, substantial, and credible utility for the claimed isolated and purified gene, the isolated and purified gene composition may be patentable. ${ }^{\text {it }}$

Em relação ao DNA dos genes, sintetizado em laboratório, o USPTO aplicou o mesmo raciocínio. Como esse DNA sintetizado não existe no mesmo estado purificado na natureza, ele é uma invenção; mesmo tendo a mesma seqüência de DNA dos organismos. O mesmo critério é aplicado a outras moléculas biológicas isoladas da natureza. $^{72}$

A patente concedida sobre uma determinada molécula biológica abrange tanto ela isolada e purificada dos tecidos biológicos como, também, ela sintetizada em laboratório, pois a estrutura bioquímica desta molécula descrita na patente é o objeto da proteção e direito de monopólio, sendo que a estrutura da molécula biológica extraida de tecidos naturais é idêntica à sua versão sintetizada artificialmente.

Ocorre que os metais também não existem em forma pura na natureza, têm que ser isolados e extraídos dos seus tecidos naturais, ou seja, os solos. A extensão à outras substâncias naturais, do raciocínio do USPTO aplicado às moléculas biológicas isoladas dos organismo, tomaria quase tudo existente na natureza apropriável pelo privilégio de monopólio da patente. Todos os metais, por exemplo, seriam patenteáveis sob esse argumento falacioso. Bastaria descrever sua estrutura atômica e seu uso industrial. Teríamos que pagar royalties pelo ferro existente nas hemácias em nosso sangue caso fồssemos vendê-lo.

ARURA. Dilip K.; ELANDER, Richard P.: MUKERJI, K. G. Handbook of applied mycology: Fungal Biotechnology. New York: Marcel Dekker Inc., 1992. v. 4, p. 1.029.

$\Rightarrow$ Traduzimos como: "é aqui. quando a solicitação divulga uma utilidade especifica, substancial, e acreditavel, para o gene isolado e purificado reivindicado. A composição isolada e purificada do gene pode ser patenteávil."

72 ESTADOS UNIDOS DA AMÉRICA. Department of Commerce. USPT( (- United States Patent and Trademark Office. op. cit., p. 1.093. 
Nada altera esse material pelo fato dele ser isolado ou purificado. Ele continua sendo exatamente igual ao encontrado nas células dos organismos na natureza. com exatamente a mesma estrutura química, não havendo, portanto, a criação de nada. $\mathrm{Na}$ síntese artificial também nada se cria, somente se copia. Copia-se a estrutura química da molécula biológica existente nos organismos e por eles sintetizada. Como Ramella enfatizava: "não havendo criação não há invenção e nem há privilégio de patente"

Este novo direito de propriedade industrial, que os EUA e UE, estão gestando, como um ovo de serpente, está se estabelecendo, de fato, lentamente, sem maiores questionamentos técnicos jurídicos pelas demais nações desenvolvidas e, o que é pior, pelos países em desenvolvimento e suas comunidades tradicionais que são as maiores vítimas desta apropriação, por meio de patentes dos seus recursos naturais biológicos e seus conhecimentos tradicionais obtidos, comumente, pela chamada biopirataria, ou seja, sem o consentimento dos seus titulares e sem a repartição de benefícios pela exploração comercial dos mesmos.

Seguindo o caminho dos EUA, também a UE passou a patentear moléculas biológicas naturais, como veremos a seguir.

\subsubsection{UE - União Européia}

As patentes de moléculas biológicas naturais na UE, estão sendo feitas com base na Diretiva 98/44/EC, de 1998.

Analisemos o Considerando n. 15, dessa Diretiva:

(I5) Considerando que nem o direito nacional nem o direito europeu de patentes (Convenção de Munique) estabelecem. por principio, uma proibição ou uma exclusão da patenteabilidude da matéria biológica;

Realmente. a Convenção de Munique, também conhecida como EPCEuropean Patent Convention, não veda a patente de matéria biológica, mas veda expressamente que descobertas sejam patenteadas.

A Convenção de Munique de 1973 (EPC) diz:

Artigo 52.

Invenções patenteáveis

l As patentes européias são concedidas para as invenções novas que implicam una actividade inventiva e são susccptiveis de aplicação indústria:

2 - Não são consideradas como invenções no sentido do parágrafo 1 particularmente: (...) 
a) As descobertas assim como as teorias cientificas e os métodos matemálicos;

(...)

As sequiências de DNA (ou ADN, em português) existentes nas células dos organismos são absolutamente idênticas às sequêencias de DNA extraídos e purificados desses tecidos e também são idênticas às seqüências do DNA sintetizadas em laboratório, que utiliza um molde de RNA natural para ser sintetizado, com o uso de enzimas transcritases reversas.

Não existe criação no DNA natural extraído ou na sua cópia sintetizada em laboratórios. Nesses casos, a criação está somente no processo de extração do DNA dos tecidos naturais e no processo de síntese de DNA em laboratório. Contudo, onde não há criação não há invenção, conforme já demonstramos anteriormente e, portanto, não pode haver privilégio de patente.

O mesmo acontece por decorrência lógica, com as demais moléculas biológicas naturais, isoladas dos organismos que as sintetizam ou sintetizadas em laboratório, após se descobrir as suas estruturas químicas. Se não há criação, não há invenção. Se não há invenção, não há e não pode haver privilégio de patente.

Ocorre que, na realidade, as empresas dos países desenvolvidos vão aos países em desenvolvimento e, a partir das indicações de uso humano existentes nos conhecimentos tradicionais, coletam plantas ou animais que já sabem terem alguma substância de valor comercial, isolam e analisam tais substâncias em laboratório, descobrindo assim a sua estrutura química, que vai ser descrita na solicitação de patente, juntamente com o uso industrial já obtido através dos conhecimentos tradicionais.

Quando a substância é uma proteina, é possível se deduzir essa provável seqüência de bases nitrogenadas do RNA que a sintetizou e, a partir daí, sc deduzir a seqüência do DNA responsável por essa proteína, localizá-la nos cromossomos, isolá-la e fazer a solicitação de sua patente para se obter o monopólio sobre o seu uso e o da própria proteína.

Nada é criado pelo solicitante nesses casos. Quem cria a seqüência de DNA, a estrutura química das demais moléculas biológicas e as suas propriedades úteis ao ser humano, é a natureza.

Portanto, essas moléculas biológicas não são invenções e sim descobertas, porque já eram pré-existentes nos organismos e, por isso mesmo, puderam ser isoladas, o que em nada altera a sua estrutura química, que é a responsável pelas propriedades que o solicitante da patente visa monopolizar. 
Portanto, como a Convenção de Munique veda expressamente a patente de descobertas, por não serem invenções (art. 52.2.a), por decorrência lógica, o considerando 15 da Diretiva é absolutamente falso.

Os considerandos continuam:

(23) Considerando que uma mera sequiência de ADN sem indicação de uma função biológica não contém quaisquer ensinamentos de natureza técnica, pelo que não poderá constituir uma invenção patenteável:

(24) Considerando que, para que o critério da aplicação industrial seja respeitado no caso de unna sequiência parcial de um gene ser utilizada para a produção de uma proteina ou proteína parcial, é necessária a especificação da proteina ou proteina parcial produzida ou da função assegurada: (grifamos)

Portanto, para patentear uma molécula biológica na UE, é necessário somente se descrever a sua função biológica e no caso do DNA apontar a proteína que ele expressa, basta descrever a sua seqüência de aminoácidos. Nem mesmo uma utilidade industrial para essa proteína é exigida. Essa é também uma distorção grave do direito de propriedade industrial em seu requisito de utilidade industrial.

(34) Considerando que a presente diretiva não afecta os conceitos de invenção e descoberta, tal como estabelecidos pelo direito de patentes, a nível nacional. Europeu ou internacional;

Ocorre que na consideração da diretiva, pelo exposto acima, é também absolutamente falsa, pois o seu art. 3.2 permite expressamente patentear uma molécula biológica mesmo que ela pré-exista no estado natural, procurando assim legalizar o patenteamento de descobertas, pois como já vimos, a principal característica da descoberta que a diferencia da invenção é justamente a sua pré-existência. Transcrevemos abaixo o art. $3^{\circ}$ da Diretiva 98/44/EC:

Artigo $3^{\circ}$

1. Para efeitos da presente dircctiva, são patenteciveis as invenções novas que impliquem uma actividade inventiva e sejam susceptiveis de aplicação industrial, mesmo quando incidam sobre um produto composto de matéria biológica ou que contenha inatéria biológica ou sobre um processo que permita produsir, tratar ou utilizar matéria biológica.

2. Uma matéria biológica isolada do seu ambiente natural ou produzida com base num processo ticnico pode ser objecto de uıma invenção, mesmo que pré-exista no estado natural. 
Portanto, a Diretiva 98/44/EC da União Européia, permite por força do seu art. 3.2, a patente de moléculas biológicas descobertas na natureza, o que conflita diretamente com o art. 52.2.a da Convenção de Munique. Ela conflita também com toda a doutrina de direito de propriedade industrial desde a sua origem e conflita até consigo mesma, pois o art. 3.1 diz expressamente que as invenções são patenteáveis e como já demonstramos, invenções são diferentes de descobertas e o que já pré-existe, como a matéria biológica natural, não é invenção, é descoberta.

Como a Convenção de Munique, ou EPC, é um acordo internacional, em que todos os países da UE são signatários e a Diretiva 98/44/EC é uma norma comunitária, resultante e, portanto, hierarquicamente inferior ao Tratado de Maastricht de 1992, que criou a UE, as disposições da Convenção de Munique são hierarquicamente superiores às da Diretiva 98/44/EC. editada pelo Parlamento e Conselho da União Européia. Assim, visto que as duas estão em conflito a prevalência deve ser das normas da Convenção de Munique e o patenteamento de moléculas biológicas naturais, como vimos, fere seus dispositivos. ${ }^{73}$

\section{Conclusões}

Os países desenvolvidos, como EUA e UE. que patenteiam moléculas biológicas naturais, ainda que isoladas de seus tecidos orgânicos estão. na verdade, regularizando juridicamente descobertas em total afronta ao direito de patentes e aos motivos que levaram à sua criação e à estipulação de limites do que pode ser objeto de privilégio de monopólio de patente.

O principal motivo para a existência desses limites à tutela do direito de patente às invenções é excluir as descobertas e, portanto, os componentes da natureza, que não podem ser monopolizáveis por motivos éticos, morais e práticos. A economia não se desenvolveria se os recursos naturais fossem todos monopolizados, ou monopolizáveis, por patentes a partir do momento em que fossem descobertos.

Esse movimento racional e articulado das empresas dos paises desenvolvidos e de seus governos visa exclusivamente obter o maior lucro possivel com a biodiversidade dos países em desenvolvimento, porque eles mesmos não têm essa biodiversidade. Os países desenvolvidos e com pequena biodiversidade detêm somente a biotecnologia, que é quase inócua sem os recursos biológicos que são a sua matériaprima.

73 ARORA. Dilip K.; ELANDER. Richard P.: MUKERJI. K. G.. op. cil., p. 1.029. 
A riqueza que sempre foi gerada pela biodiversidade, agora é potencializada pela biotecnologia. Para monopolizar essa riqueza, as empresas dos países desenvolvidos tentam travestir de invenção as descobertas que fazem, em sua maior parte, na biodiversidade dos países em desenvolvimento, explorando as riquezas destes países como fizeram durante o processo de colonização nos séculos passados.

Assim, eles procuram conferir a esse saque e roubo, uma aparência de legalidade e, conseqüentemente, legitimidade através do direito de propriedade intelectual em sua modalidade de direito de patente. Ocorre que elas não podem mudar os fatos. A invenção protegida pelo direito de patente é necessariamente algo criado e a descoberta é o conhecimento de algo preexistente.

Portanto, as moléculas biológicas naturais isoladas dos seus tecidos não são criadas, como a própria Diretiva 98/44/FC e a USPTO reconhecem, quando usam o termo isoladas, pois o que é isolado não é criado, já é preexistente para poder ser isolado, não se tratando assim de invenção. Logo, as patentes de moléculas biológicas naturais nos EUA e UE estão sendo concedidas sobre descobertas e não sobre invenções.

Por tudo exposto, concluímos que não é patenteável a criatividade das informações contidas nas estruturas das moléculas biológicas, como o DNA que compõe os genes, e das propriedades químicas e biológicas resultantes dessas estruturas, pois elas são invenção da natureza. São resultantes da criatividade do seu processo seletivo e da evolução natural, ao longo dos quatro bilhões de anos estimados do surgimento da vida na Terra, e não de quem isola em laboratórios essas moléculas dos seus tecidos naturais e apenas descobre suas estruturas, descrevendo-as em uma solicitação de patente.

Naturalmente para os religiosos, essa criatividade inventiva é de Deus que teria criado a natureza e todos os seres vivos. inclusive os humanos. Mas felizmente para nós, não consta que Ele tenha solicitado concessõcs de patente sobre suas invenções. Pelo menos, não até agora.

São Paulo, dezembro de 2006.

\section{Referências}

ARORA, Dilip K.; ELANDER, Richard P.; MUKERJI, K. G. Handbook of applied mycology: Fungal Biotechnology. New York: Marcel Dekker Inc., 1992. v. 4.

BERGEL. Salvador Dario. Patentes de genes; implicancias eticas y juridicas. Bioética, Brasilia, v. 5, n. 2, p. 243-52, 1997. 
BURNIER, Dominique. La notion de l'invention en droit europén des brevets. Genève: Librairic Droz, 1981.

DI SABATO. Franco; LO IUDICE, Bruno. Innovazioni technologiche e diritto di empresa. 2. ed. Napoli: Morano Ed.. 1982.

DOMINGUES, Douglas Gabriel. Direito Industrial e Patentes. Rio de Janeiro: Forense, 1980. - Privilégios de invenção, engenharia genética e biotecnologia. I. ed. Rio de Janeiro: Forense, 1989.

ESTADOS L:NIDOS da América. Department of Commerce. USPTO United States Patent and Trademark Office. L'tility Examination Guidelines. Washington: Federal Register. v. 66, n. 4, Friday, January 5, 200I. (Notices)

FRANCESCHELLI, Remo. Tratudo di diritto industriale. Parte generale. Milano: Giuffre Ed., 1973. v.1.

GHIRON, Mario. Corso di diritto industriale. 2. ed. rev. e ampl. Roma: Società Fditrice del "Foro Italiano", 1937. v.2.

RAMELLA, Agostino. Trattato della proprietà industriale. v.I- le inverizione industriali. Roma: Soc. Editrice Laziale, 1909.

SILVEIRA, Newton. Curso de propriedade industrial. 2. ed. São Paulo: Ed. Revista dos Tribunais, 1987.

SOARES. José Carlos T. Biotecnologia- A mais avançada tecnologia da vida. Revistu da ABPI. Rio de Janeiro, n. 10, p. 38-40, 1994.

SHIVA, Vandana [et al]. Biodiversity-social \& ecological perspectives. 2. ed. London: \%ed Books, 1995.

VIARO. Mario. La tutela del principio scientifico nel diritto d'invenzione. Milano: Giuffrè, 1970.

WIPO- World Intellectual Property Organization. .National Seminar on Innovation Promotion. Genebra. WIPO/INN/BRI/99/1. 1999. 